\title{
The green synthesis of gold nanoparticle using extract of Virola oleifera
}

\author{
Bárbara Milaneze ${ }^{1 *}$, Wanderson Keijok¹, Oliveira Jairo ${ }^{1}$, Peruch Brunelli, Bartochevis Janine ${ }^{1}$, Liqui Larissa ${ }^{1}$, \\ Prado Adilson', Endringer Denise ${ }^{2}$, Pontes Maria', Ribeiro Moises ${ }^{1}$, Nogueira Breno ${ }^{1}$, Guimarães Marco' \\ From 5th Congress of the Brazilian Biotechnology Society (SBBIOTEC) \\ Florianópolis, Brazil. 10-14 November 2013
}

\section{Background}

The green synthesis consists of an environmentally friendly method of producing gold nanoparticles (AuNP's). Physical and chemical syntheses have energy intensive and may involve toxic chemicals, while biological techniques are cost-effective, clean, non-toxic and environmentally appropriate.

Virola oleifera is widely used in folk medicine. The bark of the trunk when scraped produce a resin rich in phenolic compounds, which is used against bleeding hemorrhoids, cramping, and also has healing action of chronic wounds and ulcers, diarrhea and counter hemoptysis. It is known that the presence of phenolic extract gives the reducing action, but studies need to be done to understand what substances are involved and what the mechanisms of formation of newly synthesized nanoparticles.

Thus, the aim of this study was to describe a new route for the synthesis of AuNP's using resin of Virola oleifera with future application in nanoscience from the synthesis of nanoparticles for applications as nano biosensors.

\section{Methods}

To check the effect of variables on conversion of the reaction, as well as finding the conditions that maximized the synthesis of nanoparticles, one factorial design $\left(3^{2}\right)$ with 3 levels and 2 variables was done. The concentration of the reducing agent $(0.5,1.0$ and $2.0 \mathrm{~mL})$, and the synthesis time $(5,10$ and $15 \mathrm{~min})$. These intervals were defined based on the literature.

To prepare nanoparticles, was used the gold precursor solution $\left(\mathrm{HAuCl}_{4}\right.$ with $\left.2,5 \times 10^{-4} \mathrm{M}\right)$ and as reducer agent the resin lyophilized of Virola oleifera $(1 \mathrm{mg} / \mathrm{mL})$, both dillueted in distilled water. Based on the experimental

${ }^{1}$ Universidade Federal do Espírito Santo, Vitória, Brazil

Full list of author information is available at the end of the article design, the solution of the reducing agent was added to the gold solution and stirred for predefined times.

AuNP's samples were collected after the synthesis step and had their optical properties assessed by spectrophotometry UV-visible (SHIMADZU). The size and morphology of AuNP's were examined by transmission electron microscopy (JEM-1400, JEOL Inc, USA).

\section{Results and conclusions}

The absorption spectra of UV-Vis showing that the synthesis resin of Virola oleifera leads to the formation of nanoparticles with different optical properties according to the synthesis time and concentration of reducing agent.

The results of the electronic spectra of the solutions obtained and the analysis in the transmission electron microscope showed the difference in the absorbance spectrum of the particles. It was observed that the concentration of the reducing agent was significant in the synthesis process, and that the absorbance peaks were found in the highest concentrations of reducing agent, with consequent increase in nanoparticle size.

\footnotetext{
Authors' details

${ }^{1}$ Universidade Federal do Espírito Santo, Vitória, Brazil. ${ }^{2}$ Universidade de Vila Velha Instituto Federal do Espírito Santo, Vitoria, Brasil.

Published: 1 October 2014

\section{References}

1. Alves OL: Nanotecnologia, nanociência e nanomateriais: quando a distância entre presente e futuro não é apenas questão de tempo. Parcerias estratégicas 2004, 18.

2. Silva ALCM, Thesing A, Gutierrez MG, Ferreira J: Síntese de Nanopartículas de Ouro utilizando Óleos Essenciais de Eucalipto. Universidade Federal de Pelotas

3. Kuroshima KN: Estudos químicos e farmacológicos das plantas Virola oleifera e Hyeronima alchorneoides. Florianópolis 2002.
} 
4. Krishnendu Saha, Sarit S. Agasti, Chaekyu Kim, Xiaoning Li, Vincent M: RotelloGold Nanoparticles in Chemical and Biological Sensing. American Chemical Society, Chem Rev 2012, 112:2739-2779.

5. FERNANDES AMAP, BARATA LES, FERRI PH: Lignans and neolignans from Virola oleifera leaves. Phytochemistry 1993, 32(6):1567-1572.

doi:10.1186/1753-6561-8-S4-P29

Cite this article as: Milaneze et al:: The green synthesis of gold nanoparticle using extract of Virola oleifera. BMC Proceedings 2014 8(Suppl 4):P29.

Submit your next manuscript to BioMed Central and take full advantage of:

- Convenient online submission

- Thorough peer review

- No space constraints or color figure charges

- Immediate publication on acceptance

- Inclusion in PubMed, CAS, Scopus and Google Scholar

- Research which is freely available for redistribution 